American University Washington College of Law

Digital Commons @ American University Washington College of

Law

Articles in Law Reviews \& Other Academic Journals

Scholarship \& Research

2000

Reconciling Amnesties with Universal Jurisdiction

Juan E. Mendez

Garth Meintjes

Follow this and additional works at: https://digitalcommons.wcl.american.edu/facsch_lawrev

Part of the Criminal Law Commons, Human Rights Law Commons, International Humanitarian Law Commons, International Law Commons, and the Jurisdiction Commons 


\section{Reconciling Amnesties with Universal Jurisdiction}

GARTH MEINTJES and JUAN E. MÉNDEZ ${ }^{1}$

\section{Introduction}

Human rights bodies already have held that domestic amnesty laws may violate a state's international human rights obligations. ${ }^{2}$ Nevertheless, since these laws often continue to be applied domestically, a novel legal situation arises when an amnesty beneficiary like General Augusto Pinochet steps outside of a domestic haven into the ambit of universal jurisdiction. What deference does the international community owe in such cases to the domestic arrangements made by the state in reckoning with the serious human rights violations and international crimes of its recent past?

For many years, the answer may well have been: "complete and absolute deference." Although international human rights law places limits on what states can do to their citizens, those restrictions generally were thought to operate to prevent present and perhaps future abuses. How a newly democratic government treated past human rights abuses and crimes was considered a matter largely within its own discretion. When that treatment included some forms of clemency and oblivion (invariably justified as being for the sake of national reconciliation), this was thought to be well within the attributes of sovereignty and of little concern to the international community.

Amnesty laws obtained a bad name, however, when they became shameful tools for perpetuating the impunity enjoyed by violators of human rights, rather than opportunities for reconciliation among warring parties. Typically, these laws not only prevented victims or their families from seeking justice, they also denied them the possibility of learning the truth about the circumstances in which they were victimized. In addition, by granting impunity to the former dictators and their

\footnotetext{
'Both authors are affiliated with the Center for Civil and Human Rights, Notre Dame Law School. We gratefully acknowledge the valuable research assistance provided by Michelle L. Mack, a participant in the Center's international human rights law program. Carrie Di Santo also provided helpful revisions.

${ }^{2}$ See General Comment No. 20 (44) (art.7), U.N. Doc. CCPR/C21/REV.I/Add.3, 15 (Apr. 1992). See also Inter-American Commission on Human Rights, Report No. 24/92 (Argentina), OEA/ser. L/V/II. 82, Doc. 24 (Oct. 2, 1992); Inter-American Commission on Human Rights, Report No. 29/92 (Uruguay), OEA/ser. L/V/II. 82, Doc. 25 (Oct. 2, 1992); Inter-American Commission on Human Rights, Report on the Situation of Human Rights in El Salvador, OEA/ser. L/V/II. 85, Doc. 28 (Feb. 11, 1994); and Inter-American Commission on Human Rights, Report No. 36/96 (Chile), OEA/ser. L/V/II. 95, Doc. 25 (Oct. 15, 1996).
} 
accomplices, these laws often allowed them to retain positions from which they continued to influence the policies of the new regimes.

For political, moral and legal reasons, however, some newly democratic governments attempted to settle these accounts rather than leave them as permanent wounds in the fabric of society. In their attempts to restore justice, they were helped by principles embodied in the international law of human rights. But the reverse also has happened: international human rights law itself has been enriched by the practices and experiences of the various approaches that were attempted in dealing with the demands of truth and justice. As a result, it is now widely, perhaps universally, accepted that the abuses of the recent past require some affirmative responses on the part of the state in which they occurred. ${ }^{3}$ Moreover, these duties must be carried out regardless of whether the abuses were committed by the present or a former government.

While it is clear that no government is free to completely ignore its past, it is equally apparent that the approaches which governments thus far have adopted run the full gamut from complete impunity on the one hand to full truth and justice on the other. In virtually all cases, some element of clemency (for certain perpetrators or for certain deeds) is included in the balance of considerations. Although most efforts thus far have not met international expectations, it is unfair to color with the same degree of opprobrium a state that has made a good faith effort to confront its past, but yet has not imprisoned all perpetrators, as a state that simply has buried its past.

This point is well illustrated by the case of South Africa, as described below, where a more discerning evaluation is needed to assess the adequacy of the level of accountability that state has achieved. For in its efforts to comply with expectations of the international community, this case represents not only a rejection of broadly drawn amnesties, but also a suggestion that the criteria for granting amnesties

\footnotetext{
${ }^{3}$ See Diane Orentlicher, "Addressing Gross Human Rights Abuses: Punishment and Victim Compensation", in Human Rights: An Agenda for the New Century (Louis Henkin and John L. Hargrove eds., 1995); and Naomi Roth-Arriaza, Impunity and Human Rights in International Law (Naomi Roth-Arriaza ed., 1995) (for detailed examinations of the state of international law in this subject). See also, "Question of the impunity of perpetrators of human rights violations (civil and political): Revised final report prepared by Mr. Joinet pursuant to subcommission decision" 1996/119, U.N. Subcommission on Prevention of Discrimination and Protection of Minorities, 49th Sess., U.N. Doc. E/CN.4/Sub.2/1997/ 20/Rev. 1 (1997); and Theo Van Boven, UN Special Rapporteur on Restitution, Compensation and Reparations for Gross and Consistent Violations of Human Rights, "Study concerning the rights to restitution, compensation and rehabilitation for victims of gross violations of human rights and fundamental freedoms", U.N. ESCOR, Comm'n on Hum. Rts., 45th Sess., Provisional Agenda Item 4, U.N. Doc E/CN.4/Sub.2/1993/8 (1993).
} 
should be drawn narrowly from the general practice of states in applying the political offence exception to extradition.

At stake here is not simply a matter of moral condemnation, nor even of finding and declaring a technical violation of an international law norm. Instead, it is a judgment that may influence how the international community considers its own obligation to step in and prevent impunity for major crimes. This obligation, embodied in the principle known as "universal jurisdiction," was largely speculative until a few years ago. ${ }^{4}$ However, the principle now has been reinforced by the creation of the ad hoc war crimes tribunals for the Former Yugoslavia and Rwanda, and reconfirmed by the adoption of the Rome Statute for an International Criminal Court (hereinafter Rome Statute and ICC respectively). In addition, the recent arrest of Pinochet in the United Kingdom, at the request of a Spanish judge, has given greater recognition to another form of universal jurisdiction: a state's extraterritorial competence to prosecute international crimes committed in foreign countries.

The Pinochet case brings into focus the question with which we started this article. Among the many novel issues raised by this incident is the persistence with which the democratic government of Chile (in many ways counting itself as one of Pinochet's victims) has attempted to have him returned to his home country as a free man. In spite of those diplomatic efforts, the Chilean government nevertheless tried to maintain some legal, political and moral distance between its position and that of Pinochet's defense. For example, the Chilean government does not claim that the crimes attributed to Pinochet are not serious, or that they do not give rise to a legitimate exercise of universal jurisdiction. Rather, Chile asserts that the rest of the world should respect its efforts to deal with its tragic past, because it has already done, to the best of its ability, what the rule of law allows and what international law requires. The problem with this argument is that the crimes for which the former dictator is accused still are covered by a blanket amnesty that Pinochet himself imposed by decree in 1978. As a result, there has never been much hope for his victims to obtain legal redress in Chile for the abuses that they suffered.

\footnotetext{
${ }^{4}$ The term "universal jurisdiction" increasingly is being used to refer to states' jurisdiction to prosecute international crimes. See e.g. "International Council on Human Rights Policy", Hard Cases: Bringing Human Rights Violators to Justice Abroad - A Guide to Universal Jurisdiction (1999). Some have argued that the term only should be used for foreign - but not international - crimes over which a state may have jurisdiction. See e.g., Ian Brownlie, Principles of Public International Law 305 (4th edition 1990). For the sake of convenience we use the term in the sense in which it is increasingly being understood, i.e., as the jurisdiction states have over international crimes.
} 
In a more reasonable formulation of its argument, the Chilean government also claims that it should enjoy preference as the jurisdiction most suited to prosecute Pinochet's crimes and that it is both willing and able to do so. However, while it is true that Chilean courts are entertaining a number of criminal complaints in which Pinochet is named, few Chilean courts have thus far taken the steps necessary to tear down the walls of impunity protecting him. These barriers include the selfamnesty law, the assertion of military court jurisdiction, and his immunity as selfappointed "senator-for-life." It may well be possible, still, to prosecute Pinochet in Chile; but as Home Secretary Jack Straw pointed out in ordering extradition to proceed, this case would be more persuasive if there had been a Chilean extradition request to compete with the Spanish, Belgian, Swiss and French ones.

Whether or not the Chilean position has any merit in terms of the international community's expectations is a question that requires further attention, if for no other reason than the probability that similar arguments will be raised again in other cases following the Pinochet precedent.

\section{The Scope of the Evolving Principles of Accountability in International Law}

The principles of accountability include several that are already well established for certain specific aims of the international community, as well as others which are evolving through customary state practice or through the interpretation and application of more general state obligations. In terms of the former, it is important to note that there are already several treaties and resolutions containing explicit principles aimed at the suppression of international crimes. These principles generally apply to war crimes and crimes against humanity, and though they are by no means uniform in their scope and content, it is increasingly likely that they will be interpreted as giving rise to essentially the same obligations.

For example, the four Geneva Conventions of 1949 and Protocol I of 1977 require that all states search for and prosecute or extradite anyone responsible for "grave breaches" of international humanitarian law. ${ }^{6}$ In the past, this obligation

\footnotetext{
5See "An African Pinochet", N.Y. Times, Feb. 11, 2000.
}

"Cf. Geneva Convention for the Amelioration of the Condition of the Wounded and Sick in Armed Forces in the Field, Aug. 12, 1949, 6 U.S.T. 3114, 75 U.N.T.S. 31, art. 50; Geneva Convention for the Amelioration of the Condition of Wounded, Sick and Shipwrecked Members of Armed Forces at Sea, Aug. 12, 1949, 6 U.S.T. 3217, 75 U.N.T.S. 85, art. 51; Geneva Convention Relative to the Treatment of Prisoners of War, Aug. 12, 1949, 6 U.S.T. 3316, 75 U.N.T.S. 135, art. 130; Geneva Convention Relative to the Protection of Civilian Persons in Time of War, Aug. 12, 1949, 6 U.S.T. 3516, 75 U.N.T.S. 287, art. 147; and Protocol Additional to the Geneva Conventions of 12 August 1949, and Relating to the Protection of Victims of International Armed Conflicts, June 8, 1977 , 1125 U.N.T.S. 3, arts. 11(4), $85 \& 86$. 
may have been limited by a distinction between international and non-international armed conflicts that limited "grave breaches" to the former. However, in recent years, that distinction has been blurred and serious violations occurring in noninternational armed conflict may now give rise to similar international obligations to prosecute.

In contrast to war crimes, there still is no specific international treaty proscribing "crimes against humanity." Nevertheless, at least since Nuremberg, crimes against humanity have been viewed as international crimes. This was confirmed by the establishment of the two ad hoc international criminal tribunals in 1993 and 1994 to prosecute, among others, crimes against humanity in the former Yugoslavia and Rwanda. ${ }^{8}$ Similarly, crimes against humanity also are among the core crimes included in the Rome Statute. ${ }^{9}$

In addition to their status as international crimes, crimes against humanity also give rise to a duty on the part of states to prosecute or extradite any suspected offenders. The UN General Assembly affirmed this in a 1971 resolution, which declared it contrary to the UN Charter and to generally recognized norms of international law for a state to refuse to cooperate in the arrest, extradition, trial and punishment of persons suspected of war crimes and crimes against humanity. ${ }^{10}$ The same body provided further guidance for the fulfillment of this duty in a 1973 resolution on Principles of International Cooperation in the Detention, Arrest, Extradition, and Punishment of Persons Guilty of War Crimes and Crimes Against Humanity. ${ }^{11}$ Moreover, given the effect of the principle of complementarity under

7 See In re Dusko Tadic: Decision on the Defence Motion for Interlocutory Appeal on Jurisdiction (Prosecutor v. Tadic), 1995 I.C.T.Y. No. IT-94-1-AR72 (Oct. 2). See also Theodor Meron, "International Criminalization of Internal Atrocities", $89 \mathrm{Am}$. J. Int'l L. 554 (1995).

${ }^{8}$ See Statute of the International Tribunal for the Prosecution of Persons Responsible for Serious Violations of International Humanitarian Law Committed in the Territory of the Former Yugoslavia since 1991, UN Doc. S/25704, annex (1993), reprinted in 32 I.L.M. 1192 (1993); Statute of the International Tribunal for the Prosecution of Persons Responsible for Genocide and Other Serious Violations of International Humanitarian Law Committed in the Territory of Rwanda, SC Res. 955, UN SCOR, 49th Sess., Res. \& Dec., UN Doc. S/INF/50 (1994), reprinted in 33 I.L.M. 1602 (1994).

9 See Rome Statute of the International Criminal Court, U.N. Doc. A/CONF.183/9 (July 17, 1998) art. 7, reprinted in 37 I.L.M. 999 (1998), available in Documents (visited Oct. 22, 1999) <http://www.un.org/icc/>.

${ }^{10}$ G.A. Res. 2840 (XXVI) 26 U.N. GAOR Supp. (No. 29), at 88, U.N. Doc A/8429 (1971) cited in M. Cherif Bassiouni, 'Search for Peace and Achieving Justice: The Need for Accountability", 59 Law and Contemp. Probs. 5, 16 (1996).

$"$ G.A. Res. 3074 (XXVIII) 28 U.N. GAOR Supp. (No. 30), at 78, U.N. Doc A/9030 (1973) cited in Bassiouni, Id. at 16. 
the Rome Statute, crimes against humanity certainly will be viewed as requiring prosecution in future.

The Genocide Convention, which arguably deals with a special category of crimes against humanity, also is explicit in its obligations upon states either to prosecute or extradite suspected offenders. ${ }^{12}$ Similarly, the Torture Convention imposes an explicit obligation on states either to prosecute or extradite anyone suspected of committing torture. ${ }^{13}$

In addition to the explicit obligations attached to international crimes by treaties, there are a number of "emerging principles" that are considered binding on states because they are authoritative interpretations of other more general treaty obligations or because they are supported by state practice. In essence, these norms require, with respect to certain human rights violations, that the state take the most effective steps available to restore a measure of justice for the victims and their families and to prevent future violations. A failure to do so may, in some cases, serve to undermine a state's legitimacy and standing in the eyes of the international community, while in others it could result in the ICC or foreign courts stepping in to do justice where the responsible state has failed.

These principles apply to a relatively narrow class of human rights violations those affecting rights so fundamental that they put in question the diligence with which a state is adhering to its obligation to respect and ensure all internationally guaranteed rights. ${ }^{14}$ These principles are further reinforced by the general obligation on states to provide effective remedies for all human rights violations..$^{15}$ This is particularly the case where the most effective remedy available may be to investigate and prosecute a serious violation of the past. ${ }^{16}$ These emerging principles at least

12 Convention on the Prevention and Punishment of the Crime of Genocide, GA Res. 260 A (III) of 9 December 1948 (Entry into force 12 January 1951) arts. I, V \& VII.

13 See Convention Against Torture and Other Cruel, Inhuman or Degrading Treatment or Punishment, G.A. Res. 39/46, U.N. GAOR, 39th Sess., U.N. Doc. E/CN.4/1984/72 (1984), arts. $5 \& 7$ [hereinafter Torture Convention] (requiring state parties to assume jurisdiction over torture committed anywhere, and to prosecute or extradite suspected perpetrators within its jurisdiction).

${ }^{14}$ See International Covenant on Civil and Political Rights, Dec. 16, 1966, 999 U.N.T.S. 171 , arts. $3(1) \& 3(2)$.

15 See Id. art. 3(3). See generally, Dinah Shelton, Remedies in International Human Rights Law (1999).

${ }^{16}$ See $X$ \& $Y$ v. The Netherlands, 91 Eur. Ct. H. R. (ser. A) (1985) Case No. 16/1983/72/ 110 (where the court held, in a case not involving widespread or systematic abuses, that criminalization and prosecution are still required in order to effectively ensure the victim's right to privacy, where this offers the most effective protection against rape). 
can be said to cover cases involving political murders, massacres, disappearances, torture and prolonged arbitrary detention.

Several obligations are imposed by these emerging principles of accountability on the state where the violations occurred. The abuses must be investigated and, where crimes are discovered, the perpetrators must be prosecuted and punished. ${ }^{17}$ To the extent these crimes were kept secret in any important regard, such as in the forced disappearance of persons, the state must also discover the truth and disclose it to families and to society. ${ }^{18}$ States must also provide redress to the victims and take measures to prevent repetition. Chief among the latter is the obligation to disqualify known perpetrators from the ranks of police and security forces, whether or not they also can be punished. ${ }^{19}$

It must be noted, however, that not all of these obligations are necessarily absolute. In fact, in some cases, international law only imposes obligations of means and not of results. In other words, what is required is a process conducted in good faith and "not as ritual destined to failure." ${ }^{20}$ On the other hand, these obligations are not options from which each government can choose; each one must be performed in good faith and to the best of the state's abilities. ${ }^{21}$ Moreover, even in cases where the state has met its international obligations, a foreign court may legitimately invoke universal jurisdiction to prosecute certain crimes that were inadequately prosecured at the domestic level. It is therefore important to establish benchmarks to determine when states have either satisfied or fallen short of the international

17 Velásquez Rodriguez v. Honduras, Merits, Judgment of July 29, 1988, Inter-Am. Ct. H.R., Ser. C, No. 4 (1988).

${ }_{18}$ Juan E. Méndez, "The Right to Truth", in Association Internationale de Droit Pénal, Nouvelles Istudes Pénales, No. 14, Reining in Impunity for International Crimes and Serious Violations of Fundamental Human Rights: Proceedings of the Siracusa Conference 255 (Christopher C. Joyner \& M. Cherif Bassiouni, eds., 1998).

19) See U.N. Human Rights Committee, "Concluding Observations of the Human Rights Committee: El Salvador, Consideration of Reports Submitted by States Parties Under Article 40 of the Covenant" (Sept. 21, 1994) U.N. Doc. CCPR/C/79/Add.34; A/49/40, 99 209-224; U.N. Human Rights Committee, "Concluding observations of the Human Rights Committee: Argentina, Consideration of Reports Submitted by States Parties Under Article 40 of the Covenant" (April 5, 1995) U.N. Doc. CCPR/C/79/Add.46; A/50/40, I9 144-165; and U.N. Human Rights Committee, "Concluding Observations of the Human Rights Committee: Peru, Consideration of Reports Submitted by States Parties Under Article 40 of the Covenant" (July 25, 1996) U.N. Doc. CCPR/C/79/Add.67 (where it has consistently maintained that the continued service of known perpetrators in the security forces creates an "atmosphere of impunity.").

${ }^{20}$ See Velásquez, supra note 13.

${ }^{21}$ See Juan E. Méndez, "Accountability for Past Abuses", 19 Hum. Rts. Q., 255 May 1997. 
community's interest in accountability. Societies making serious efforts to come to terms with their past should be rewarded, whereas leaders - even those democratically elected - who prevent the truth from being known or justice from being done, deserve international condemnation.

\section{Ensuring Compliance}

The same principles that establish obligations for states to prosecute or extradite certain offenders also establish the right and the duty of the international community to intervene where local authorities are unwilling or unable to perform their duties. Thus far, slightly different indications have been given as to when the international community will step in to exercise its jurisdiction in the place of domestic courts. In the cases of the International Criminal Tribunal for the former Yugoslavia (ICTY) and International Criminal Tribunal for Rwanda (ICTR), the Security Council resolutions establishing the tribunals granted them primacy over any prosecution being brought before a domestic jurisdiction for crimes falling within the tribunals' jurisdictions. Thus, it was left entirely to the discretion of the international courts to decide when they should exercise their jurisdiction.

By comparison, the Rome Statute does not grant the ICC primary jurisdiction over domestic prosecutions, but instead provides only for complementary jurisdiction. ${ }^{22}$ Under this principle, domestic efforts to do justice - by any state having jurisdiction - are given preference over international efforts. It is clear, therefore, that the ICC's jurisdiction is not intended to replace that of domestic courts or even of foreign courts invoking universal jurisdiction. However, to prevent abuses of this provision, the ICC will not be limited to a purely formal enquiry into the validity of other jurisdictional claims. Instead, it also will consider whether a state claiming jurisdiction is willing and able to genuinely carry out an investigation or prosecution and, where a state already has done so and decided not to prosecute, whether the decision resulted from an unwillingness or inability to genuinely prosecute. $^{23}$

In defining the ICC's jurisdiction in relation to domestic prosecutions, the Rome Statute makes no mention of domestic amnesties. It is reasonable, therefore, to infer that the ICC's jurisdiction will not be barred by such measures, except possibly

\footnotetext{
22 See Rome Statute, supra note 9, art. 17.

${ }^{23}$ Id. It must be recalled that this clause was the subject of prolonged and substantive debate. Some delegates wanted to interpret the principle of "complementarity" as meaning that a simple expression of interest by a State should be enough to bar any ICC intervention. In the end, some states that voted in favor of the Rome Statute expressed their reluctance do so over the fact that local decisions on amnesty and memory could be reviewable by the ICC.
} 
where they are part of a process that substantively satisfies the expectations of the international community. Nevertheless, even if domestic amnesties cannot be used as a procedural bar to ICC jurisdiction, what those amnesties reveal about the state's willingness and ability to do justice may influence the discretion of the ICC in deciding whether or not to exercise its own jurisdiction. The same may be said of the discretion of any prosecutor acting under universal jurisdiction. Again, this raises the question of what deference the international community should show towards domestic efforts to deal with the past. Or to put it more positively, how can a state deal with its past in a way that satisfies the expectations of the international community?

\section{Considerations Influencing the Expectations of the International Community}

We believe the inquiry into whether a state's treatment of its past satisfies the expectations of the international community should start with an examination of the general efforts towards accountability implemented at the national level. However, as illustrated by the Rome Statute's treatment of the issue of complementarity, it also will be necessary to examine the particularities of each individual case to determine whether the international community's expectations regarding individual accountability have been met.

There is no longer any question about the fact that dealing with the past by simply adopting a blanket amnesty is always unacceptable. By "blanket amnesty," we mean a law that applies across the board without requiring any application on the part of the beneficiary or even an initial inquiry into the facts to determine if they fit the law's scope of application..$^{24}$ The same may be said of a "self-amnesty" passed by a military dictatorship as a condition for leaving office. ${ }^{25} \mathrm{~A}$ more difficult case arises where a "pseudo-amnesty" has been passed by a successor democratic

\footnotetext{
${ }^{24}$ In the 1980 s, a Chilean judge (A. Cerda) devised a doctrine by which he would investigate the facts in order to reach a preliminary determination of whether Pinochet's self-amnesty law applied to them. His superiors in the judiciary prevented him from doing so and forced him into early retirement.

${ }^{25}$ The Inter-American Commission on Human Rights early on pronounced the international illegitimacy of self-amnesty laws (Speech of Amb. Oliver Jackman, President, before the First Committee of XIX Regular Meeting of the General Assembly of the OAS to present the Annual Report of the IACHR, November 1989, cited in Diane Orentlicher, "Addressing Gross Human Rights Abuses: Punishment and Victim Compensation" in Human Rights: An Agenda for the Next Century, L. Henkin and J.L. Hargrove, eds., ASIL. Washington, 1994). In some domestic jurisdictions they have been declared "null and void" and thus without any legal effect. See Juan E. Méndez, Truth and Partial Justice in Argentina: An Update, Americas Watch, (1991).
} 
regime. ${ }^{26}$ In such a case, it is sometimes difficult to ascertain whether the democratic government is operating under coercion or out of its own conscientious beliefs about what the country needs.

Nevertheless, in our view, states that have passed blanket amnesties and have resisted efforts to moderate their negative impact cannot expect any deference from the international community. Their laws may continue to have domestic effect, at least until such time as more enlightened leadership reviews them, but egregious violators who benefit from them can and must be prosecuted by future international tribunals or by courts of other countries exercising universal jurisdiction.

States that have sweeping amnesty laws but attempt other means of redressing the past and honoring the victims' plight present more complex cases. Chile is an example of such a case. Not only was its truth and reconciliation commission a good faith effort to establish the truth about the past, but the democratic government of President Aylwin also tried - albeit unsuccessfully because of the legacy of artificial majorities left by Pinochet - to repeal the self-amnesty laws. Nevertheless, the impunity enjoyed by the military in Chile has been declared inconsistent with the country's obligations under the American Convention on Human Rights. ${ }^{27}$ Since the linchpin that protects criminals from prosecution is a blanket amnesty law, Chile cannot expect the rest of the international community to apply it as its own courts do.

An easier case is that of El Salvador, where the Truth Commission investigation, reluctantly agreed to by the right-wing ARENA government, was almost exclusively an effort by the United Nations. Unfortunately, its recommendations have not

${ }^{26}$ By "pseudo-amnesty" laws we mean statutes designed to have the same effect as amnesty laws, or something very close to it, while avoiding the damning name of amnesty. See e.g., Robert K. Goldman and Cynthia Brown, Challenging Impunity: The Ley de Caducidad and the Referendum Campaign in Uruguay, Americas Watch 5-9 (1989) (describing the impunity created by Uruguay's Ley de Caducidad de la Pretension Punitiva del Estado); and Juan E. Méndez, Truth and Partial Justice in Argentina: An Update, Americas Watch, (1991) (for a description of the effects of Argentina's Punto Final (Full Stop) and Obediencia Debida (Due Obediencia) laws which benefited whole categories of potential defendants). Similarly, consider the Salvadoran amnesty passed right after the UN Truth Commission issued its report on El Salvador; and the Peruvian law especially designed to exculpate the recently convicted members of the military covert operations team that killed ten students and a professor of the La Cantuta Teachers University (Abusando de la Voluntad Popular (editorial) in IDEELE, Lima, No. 77, July 1995). It almost goes without saying that, in each of these cases, military and other undue pressures on the legislative branch are not difficult to prove.

27 See Inter-American Commission on Human Rights, Report No. 25/98 (Chile), OEA/ Ser.L/V/II.98, Doc. 6 (Feb. 17, 1998). 
been implemented. The government did separate from the ranks a number of officers named in a separate inquiry by a so-called Ad Hoc Commission, also a part of the peace process. But otherwise no effort has been made to achieve justice for the tens of thousands of victims of the cruel war of the 1980s. As a result, notorious criminals from that era should expect to be tried if apprehended abroad.

Argentina presents one of the most complex cases. Its efforts to deal with the past reflect a high degree of compliance with international standards; however, this initial compliance was later followed by backtracking by successive democratic governments acting under pressure. Argentina not only produced an exemplary truth report by a commission chaired by writer Ernesto Sabato, but also succeeded in bringing the principal perpetrators, including three former Presidents, to justice. ${ }^{28}$ Only later were laws constituting a blanket amnesty adopted to obstruct further attempts at prosecution, while President Carlos S. Menem pardoned the remaining prisoners awaiting trial or serving sentences in 1989 and 1990. Nevertheless, over the years, Argentina has continued to insist on different forms of accountability. Several courts are still investigating events of the "dirty war" for purposes of disclosing the truth to the relatives of the victims and to society, and in some cases they are even compelling testimony. ${ }^{29}$ In the 1990 s, the Chief of the Army repeatedly condemned the "dirty war" tactics of his comrades-in-arms and apologized to the nation for them. The offense of stealing children from their "disappeared" mothers and giving them in irregular adoptions was deliberately exempted from the amnesties and, at long last, several cases are being prosecuted for these crimes. Thanks to these proceedings, General Jorge R. Videla and Admiral Emilio Massera are back in custody under house arrest, while a number of other defendants are in prison.

On another front, Judge Baltazar Garzon, the Spanish Judge who issued a warrant for Pinochet's arrest, also has sent a request to Argentina for the extradition of about 100 officers (including Videla and Massera) for a variety of crimes he is investigating. President Menem refused to cooperate on the basis of Argentina's sovereignty. To his credit, his successor, President Fernando De la Rúa has allowed the request to go to the Argentine courts. It is too early to tell how the request will be treated, but it presents an interesting opportunity to reflect on how such cases should be viewed by the international community. For present purposes, we will

${ }_{28}$ See Carlos Santiago Nino, Radical Evil on Trial (1996). See also Ronald Dworkin, Introduction to Comision Nacional Sobre la Desaparicion de Personas, Nunca Mas: The Report of the Argentine National Commission on the Disappeared (Writers and Scholars International trans., Farrar Strauss Giroux 1986)(1984).

${ }^{29}$ The Argentine Supreme Court fashioned this "right to truth" in a case called Urteaga, in 1998. 
assume that Judge Garzón has sufficient evidence to support the extradition request and that it is otherwise formally and materially valid.

To the extent that the request includes cases involving child abduction, Argentina is entitled to refuse to comply, because it has a superior claim to jurisdiction and the cases are actively being prosecuted in good faith. A slightly harder case is that of the generals who were convicted and imprisoned for a period before being released under a pardon granted years later. They have a strong defense under the rule against double jeopardy (non bis in idem) which the international community almost certainly will honor. However, if Garzón has charged them with crimes that were not properly tried in Argentina, then the extradition could of course proceed for those charges. Finally, there does not appear to be any reason why the international community would not support the extradition of those officers who were shielded from justice by the Full Stop or Due Obedience laws, which the Inter-American Commission found to be inconsistent with Argentina's human rights obligations. ${ }^{30}$

The cases of Guatemala and South Africa are much harder. To begin with, the amnesty laws in each country were not the usual blanket amnesties that have been witnessed in so many other countries. In fact, the Guatemalan law was the first of the Latin American laws that tried to track the international law exceptions regarding amnesty, even though some aspects of it are still controversial. ${ }^{31}$ In addition, the UN-brokered peace process yielded an exemplary plan to deal with the past. In fact, the resulting report of the Commission on Historical Clarification has surprised most skeptical observers. ${ }^{32}$ Nevertheless, the fact that the amnesty law avoids the pitfalls of a blanket amnesty is no guarantee that justice will prevail. The mechanisms of de facto impunity are still very much at work in Guatemala, as demonstrated by the botched investigation of the murder of Monsignor Juan Gerardi in 1998 (well after the end of the conflict). ${ }^{33}$ Unless significant progress is made in the future, it

30 See Inter-American Commission on Human Rights, Report No. 24/92 (Argentina), OEA/ser. L/V/II. 82, Doc. 24 (Oct. 2, 1992).

31 See Douglas Cassel, "Accountability for International Crime and Serious Violations of Fundamental Rights: Lessons from the Americas: Guidelines for the International Response to Amnesties for Atrocities", 59 Law \& Contemp. Probs. 197 (1996).

32 See Commission for Historical Clarification, Guatemala: Mernory of Silence (February 24 , 1999). The Commission was part of the UN-sponsored peace process: see Agreement on the Establishment of the Commission for the Historical Clarification of Human Rights Violations and Incidents of Violence that Have Caused Suffering to the Guatemalan Population, UN GASC (48th session), UN Doc A/48/954, Annex II, 23 June 1994. See also Guatemala: Nunca Mas, Officina de Derechos Humanos del Arzobispado de Guatemala, Informe Proyecto Interdiocesano de Recuperacion de la Memoria Historica (1998).

${ }^{33}$ Francisco Goldman, "Murder Comes to the Bishop", The New Yorker, March 15, 1999. 
is likely that the international community will support international or foreign prosecutions of those responsible of the most serious abuses.

\section{The Case of South Africa}

The South African case is a significant step in the evolution of domestic efforts to deal with the past in a manner that satisfies the requirements of international law. In part this is because South Africa had the benefit of drawing on the experiences of other states. ${ }^{34}$ As a result, the innovative approach adopted avoids the pitfalls of a general amnesia about the past and instead reiterates the fundamental importance of truth telling as the foundation for a stable democracy. What makes this approach so unique, is its attempt to combine the truth telling with the selective granting of individual amnesties in a manner that meets the international community's expectations of accountability. ${ }^{35}$

In examining the South African case, it should be noted at the outset that members of the former government's military insisted upon a promise of amnesty as a condition for allowing the transition to go forward. This could easily have led to the adoption of a general amnesty giving complete impunity to all sides involved in the conflict. If it had, the amnesty process would have differed little from the practices of so many states before it and contributed nothing towards the creation of a climate of accountability. Yet to its considerable credit, the new African National

${ }^{34}$ See generally, Neil J. Kritz (ed.), Transitional Justice (1995) (for a collection of literature and documents dealing with various approaches to transitional justice); A. James McAdams (ed.), Transitional Justice and the Rule of Law in New Democracies (1997) (for a comparison of several approaches to transitional justice).

35 See John Dugard, "Reconciliation And Justice: The South African Experience", 8 Transnat'l L. \& Contemp. Probs. 277, 301 Fall, 1998 (noting that the international community has given its full support for the South African truth and reconciliation process). See also "Explanatory Memorandum To The Parliamentary Bill", available in Legal Background to the TRC (visited Feb. 10,2000) <http://www.truth.org.za/>, where the following explicit acknowledgement is made of South African international obligations:

International experience shows that, if we are to achieve unity and morally acceptable reconciliation, it is necessary that the truth about gross violations of human rights must be:-

established by an official investigation unit using fair procedures;

fully and unreservedly acknowledged by the perpetrators;

made known to the public, together with the identity of the planners, perpetrators and victims.

International human rights norms demand that any newly established government should deal with past gross violations of human rights in a way that ensures that the above mentioned requirements are met. 
Congress-led government chose instead to regard its promise not as a commitment to bury the past, but as an obligation to reveal the truth about the past in order to provide a foundation for possible reconciliation. ${ }^{36}$ To do this, it sought to devise a process that would demonstrate the new government's legitimacy and be compatible with South Africa's international obligations.

Towards this end, the South African Parliament adopted the Promotion of National Unity and Reconciliation Act 34 of 1995 (hereinafter Act) to create the Truth and Reconciliation Commission. Its mandate was to promote unity and reconciliation by establishing as complete a picture as possible of the causes, nature, and extent of the gross violations of human rights committed during the apartheid era. ${ }^{37}$ In carrying out its mandate, the Truth and Reconciliation Commission was required to consider both the perspectives of the victims and the motives and perspectives of the perpetrators. ${ }^{38}$ In doing so, it was also required to facilitate the granting of amnesty to persons who made full disclosures of all the relevant facts relating to acts associated with a political objective. ${ }^{39}$

${ }^{36}$ Dullah Omar, Minister of Justice, in his introduction of the decision to establish the Truth and Reconciliation Commission stated:

There is a commitment to break with the past, to heal the wounds of the past, to forgive but not to forget and to build a future based on respect for human rights. This new reality in the human rights situation in South Africa places a great responsibility upon all of us. Human rights is (sic) not a gift handed down as a favour by government or state to loyal citizens. It is the right of every citizen. Part of our joint responsibility is to help illuminate the way, chart the road forward and provide South Africa with beacons or guidelines based on international experiences as we traverse the transition. ... [A truth] commission is a necessary exercise to enable South Africans to come to terms with their past on a morally accepted basis and to advance the cause of reconciliation.

"Introduction by the Minister of Justice, Mr Dullah Omar", available in Legal Background to the TRC (visited Feb. 10, 2000) <http://www.truth.org.za/>.

${ }^{37}$ South Africa undertook to deal with its past dating back to March 1, 1960, twenty days before the Sharpville massacre and a year before it obtained independence from Britain. The question of whether international law requires that South Africa delve deeper into its past will not be addressed here. In any event, this is probably an appropriate temporal restriction, since this is the period during which the worst acts of violence and repression took place, see Allister Sparks, The Mind of South Africa 242 (1990). Furthermore, it is unlikely that the question of international accountability for acts which occurred before 1960 will ever arise, although the practice of apartheid, which was later condemned by the UN General Assembly as a crime against humanity, was already being implemented well before that date.

${ }^{38}$ Promotion of National Unity and Reconciliation Act 34 of 1995, Section 3(1)(a) (S. Afr.).

${ }^{39}$ Id. Section 3(1)(b). 


\section{General Considerations About the South African Approach}

The South African Truth and Reconciliation Commission produced a comprehensive five-volume report documenting the gross violations of human rights committed by all sides during the apartheid era. The report contains the findings of the Commission's own investigations as well as testimony provided by a vast number of victims and witnesses. Unlike many previous truth commissions in other states, the South African Commission did not need to rely solely on the participation of victims and non-governmental groups. Instead, the Commission also had the power to subpoena witnesses and to grant amnesty to those who met the Act's criteria and made full disclosures of their crimes. The Commission has also issued a number of recommendations aimed at victims' rehabilitation and the healing of society.

From the point of view of accountability, South Africa's individualized and conditional approach towards the granting of amnesty is highly commendable in that it avoids the dangers of a blanket amnesty. Instead, it more closely resembles a process of pardoning rather than of oblivion. Moreover, to the extent that amnesty applicants are required expressly to acknowledge both the criminality of their actions and their culpability, it should be seen as upholding rather than denying the victims' right to justice. ${ }^{40}$

Unfortunately, the South African amnesty approach also had the negative consequence of granting immunity to civil liability. Ostensibly, this was done to prevent victims from basing their claims for civil damages upon the confessions elicited by the Truth Commission. This part of the process is a violation of the victims' right to seek redress for abuses of their internationally guaranteed human rights. Such abuses are wrongs against the victims rather than the state and, as such, can only be forgiven by the victims themselves. The state may promise to indemnify the amnesty recipients if it believes that it is in the public interest to do so, but it may not simply abrogate the victims' right to seek redress. ${ }^{4 !}$

${ }^{40}$ It should be noted that, while international law gives victims the right to demand that those who violate their human rights be held accountable, it does not give them a right to insist that such violators be punished. This does not mean that punishment is irrelevant to the pursuit of justice or the rule of law, but only that decisions regarding punishment must be based on the interests of society as a whole and not exclusively on the rights of the victims. Of course, if decisions regarding punishment are not made judiciously and in a manner which maintains the deterrent effect of national and international prohibitions, then they violate the state's duty to "respect and ensure human rights" and do not merit the respect of the international community.

${ }^{41}$ The Truth and Reconciliation Act did ameliorate the injustice done to the victims by creating a Reparation and Rehabilitation Committee to grant compensation to those victims who filed requests with the Commission. 
This serious flaw in the South African truth and reconciliation process notwithstanding, the approach did hold the promise of being able to uncover the full scope of the widespread and systematic crimes of both the former government and its opponents. But its potential for doing so depended on the willingness of the rank and file to implicate those higher up the chain of command. If it had worked as had been hoped, it may well have demonstrated that the apartheid regime not only was filled with criminals, but that it was by its very nature also a criminal regime. ${ }^{42}$ Unfortunately, the results thus far appear to have fallen short of this intended goal.

One major reason for the apparent underachievement is that the threat of prosecution was not sufficiently credible. This was due to several factors that were outside the Truth and Reconciliation Commission's control. First and most significantly, an incompetent, possibly even halfhearted, effort to prosecute the former Minister of Defence by the Attorney General of Natal, even before the Commission started its work, showed the former government that they had little to fear from a judiciary still dominated by the old guard. The trial of General Magnus Malan and others for the killing of thirteen innocent civilians under the mistaken belief that they were members of an alleged terrorist group was so poorly prosecuted that the trial judge was compelled to severely admonish the prosecutor.

Second, in an effort to allay white fears of a witch hunt, the new government emphasized the rhetoric of reconciliation so unremittingly that it left itself little room for making credible threats of prosecution. It is hard to fault someone for being too forgiving, yet there should be little doubt that President Mandelas efforts to create a climate of reconciliation did not help the process of trading amnesties for truth. Ironically, the result is that South Africans now seem further apart than they were before the start of the truth and reconciliation process.

Third, the behavior of some African National Congress (ANC) officials reflected their own discomfort at delving too deeply into the past, especially regarding the allegations of torture in its training camps. ${ }^{43}$ By not showing sufficient willingness to face their own wrongs, these ANC members signaled to others their eagerness to close the book on the past and to get on with the future. Under these circumstances it is hardly surprising that many of those responsible for gross human rights violations did not believe that the government would have the stomach for a drawn out series of prosecutions.

42 Cf. Tina Rosenberg, The Haunted Land: Facing Europe's Ghosts After Communism 397-407 (1996) (for a description of the differences between regimes of criminals and criminal regimes).

43 See generally Eddie Koch, "Go to Truth Commission, ANC Tells Members", Weekly Mail, March 15, 1996. 
Perhaps the most important reason for the Truth and Reconciliation Commission's underachievement is the steadfast refusal by most of the former government officials to show any degree of sincere remorse. No one who followed the proceedings closely could have failed to notice the complete lack of symmetry between the forgiveness urged by President Mandela and the rather sparse number of matterof-fact acknowledgments from members of the former government. Moreover, not only did former Presidents Botha and De Klerk refuse to seek amnesty or forgiveness, they also actively sought to undermine and discredit the entire truth and reconciliation process.

Although these outside constraints have had a significant impact on the Truth and Reconciliation Commission's efforts, it would be a mistake to pass any final judgements on the success or failure of the South African approach. Not only would this be premature, since the work of the Commission has not yet ended with the issuing of its report, but it also would be unduly speculative, since much will depend on how the new government will build upon the foundations laid. In particular, the integrity of the process will depend on how firm the new government remains in its commitment to prosecute those who did not apply for amnesty. Justice is not necessarily incompatible with acts of forgiveness or pardon, but it can never be reconciled with a state of impunity.

\section{Specific Considerations Concerning Individual Accountability in the South African Context}

The work of the Truth and Reconciliation Commission's Amnesty Committee is not yet complete, but the indications thus far are that it has not led to widespread impunity. Indeed, the preliminary numbers suggest something very different. Of the approximately 6850 applications that were received, roughly $80 \%$ have already been denied or withdrawn. ${ }^{44}$ Admittedly, about half of these applications came from perpetrators who were already serving prison sentences for crimes that were largely unrelated to the political conflict. By comparison, only about one-tenth of the total number of applicants have thus far received amnesty. ${ }^{45}$ Moreover, of these, more than three-fifths were members of the ANC or Pan African Congress and not functionaries or agents of the apartheid-state. ${ }^{46}$

As these numbers indicate, the main beneficiaries of the amnesty process do not appear to have been the generals and apartheid leadership who had insisted upon it

\footnotetext{
44 "TRC: Current Status and Statistics", TRC Mailing List: Message \#53, December 10, 1999, available in ListBot Archives (visited January 27, 2000) <http://www.truth.org.za/>.

${ }^{45}$ Id.

${ }^{46} I d$.
} 
as a condition for allowing the transition to go forward. In fact, most of them never even bothered to apply. Thus far, only one member of the National Party, Adriaan Vlok, the former minister of law and order, has received amnesty together with 124 members of the security forces. ${ }^{47}$ Interestingly, of this number, most appear to have been police and security branch officers, not members of the military. Why the military generally chose not to avail themselves of the opportunity to seek immunity remains to be explained. One reason may be the fact that most of the soldiers were conscripts and not career soldiers inculturated into a repressive state apparatus. As such, they may have been responsible for less of the state sponsored violence. They may also feel that all that they did was fight a war against the threat of insurgents, and thus have nothing to apologize for. Or perhaps they are simply confident that most of their crimes will remain buried in the neighboring states where much of the conflict occurred.

While it is promising that the truth and reconciliation process does not appear to have led to widespread impunity, this alone is not enough to determine whether South Africa's approach complies the principles of accountability and the expectations of the international community. Instead, it is necessary, at least as far as individual accountability created by universal jurisdiction is concern, to look closely at the criteria by which the amnesties were granted and the manner in which the criteria were applied in each case.

The criteria used appear to have been developed from a combination of the political offense exception to extradition and quasi just war principles. ${ }^{48}$ As set forth in Article 20 of the Truth and Reconciliation Act, the two main criteria are: 1) that the criminal act be associated with a political objective committed in the course of the conflicts of the past; and 2) that the applicant make a full disclosure of all relevant facts. In defining the term "political objective," the Act limits its application to persons who acted on behalf of the state or known political organizations or groups. Further, in deciding whether a particular act qualifies as an act associated with a political objective, the Amnesty Committee is required to consider the a number of additional characteristics, the most important of which is the proportionality of the crime to the political objective being pursued. ${ }^{4}$

\footnotetext{
${ }^{47}$ Id.

${ }^{48}$ Promotion Of National Unity And Reconciliation Act, Act No. 34 of 1995, art. 20 (S. Afr.)
}

49 See Id. art. 20 (3): Whether a particular act, omission or offence contemplated in subsection (2) is an act associated with a political objective, shall be decided with reference to the following criteria:

(a) The motive of the person who committed the act, omission or offence; 
The decision to base the criteria on the political offence exception to extradition is interesting in that it largely coincides with the international community's expectations of accountability. If states generally do not believe that a certain kind of offence merits the extradition of a suspect from one state to another for trial and punishment, then granting amnesty for those who have committed such crimes likewise may not offend the expectations of the international community. Unfortunately, the Act does not also explicitly include any of the important exceptions which states have developed, preventing the political offence exception from applying to war crimes and crimes against humanity. However, depending on the interpretation given to it by the Amnesty Committee, it is possible that the proportionality requirement could still serve to secure the interests of the international community in suppressing such crimes. Indeed, as one of the central principles of international humanitarian law and just war theory, proportionality is one of the most widely recognized and supported restrictions on the use of violence, and one that the international community would expect South Africa to follow.

(b) the context in which the act, omission or offence took place, and in particular whether the act, omission or offence was committed in the course of or as part of a political uprising, disturbance or event, or in reaction thereto;

(c) the legal and factual nature of the act, omission or offence, including the gravity of the act, omission or offence;

(d) the object or objective of the act, omission or offence, and in particular whether the act, omission or offence was primarily directed at a political opponent or State property or personnel or against private property or individuals;

(e) whether the act, omission or offence was committed in the execution of an order of, or on behalf of, or with the approval of, the organisation, institution, liberation movement or body of which the person who committed the act was a member, an agent or a supporter; and

(f) the relationship between the act, omission or offence and the political objective pursued, and in particular the directness and proximity of the relationship and the proportionality of the act, omission or offence to the objective pursued, but does not include any act, omission or offence committed by any person referred to in subsection (2) who acted -

(i) for personal gain: Provided that an act, omission or offence by any person who acted and received money or anything of value as an informer of the State or a former state, political organisation or liberation movement, shall not be excluded only on the grounds of that person having received money or anything of value for his or her information; or

(ii) out of personal malice, ill-will or spite, directed against the victim of the acts committed. 
A detailed assessment of whether South Africa's amnesty criteria have been interpreted and applied in a manner that satisfies the international community's principles of accountability is beyond the scope of this paper. However, as the following examples illustrate, whether a particular amnesty merits the respect of the international community can only be determined by an examination of the facts and decision in each case. In some cases the decisions reveal a careful and strict application of the criteria, while in others the results appear far more questionable.

For example, in the case of Steve Biko, a prominent black consciousness leader, who died in a police interrogation room, the Committee refused to grant amnesty to five police officers who confessed to having caused his death. In their testimony the police indicated that they only used force to subdue Biko when he became combative and that they did not intentionally assault or kill him. With regard to the application of one of the officers, Gideon Johannes Niewoudt, the Amnesty Committee found that he had failed to confess to a crime and, therefore, that no amnesty could be granted. ${ }^{50}$ Similarly, with regard to the applications by the four other officers, the Committee found that they had failed to disclose a crime and that the allegedly "unintentional" killing could not have been actuated by a political motive. Moreover, even without these findings, the Committee was "satisfied that the killing of Biko was wholly disproportionate to any possible objective pursued by the applicants." 51

Had the applicants received amnesty in this case, it is unlikely that the decision would have met the expectations of the international community. The death of Biko was quite possibly the result of torture and, if so, it was clearly an international crime subject to universal jurisdiction.

A more difficult case is the assassination of Chris Hani, a well-known and popular leader in the ANC and South African Communist Party. Here the Committee found that, although Janusz J. Walus and Clive J. Derby-Lewis were members of the Conservative Party (CP) and the latter a former Member of Parliament, they were not acting on the orders of the CP when they conspired and shot Mr. Hani. ${ }^{52}$

\footnotetext{
50 "Application In Terms Of Section 18 Of The Promotion Of National Unity And Reconciliation Act, No. 34 Of 1995, Gideon Johannes Niewoudt Applicant", Truth and Reconciliation Commission, Amnesty Committee AC/98/0114 (S. Afr.), available in Decisions (visited February 23, 2000) <http://www.truth.org.za/>.

51 "Application In Terms Of Section 18 Of The Promotion Of National Unity And Reconciliation Act, No. 34 Of 1995, Harold Snyman et al. Applicants", Truth and Reconciliation Commission, Amnesty Committee AC/99/0020 (S. Afr.), available in Decisions (visited February 23, 2000) <http://www.truth.org.za/>.

52 "Application In Terms Of Section 18 Of The Promotion Of National Unity And Reconciliation Act, No. 34 Of 1995, Janusz J. Walus and Clive J. Derby-Lewis Applicants",
} 
Because they were not acting on behalf of a known political group or party when committing their crime, they were not eligible for amnesty under the Act. Had the decision been different in this case, it would have been difficult from an international humanitarian law perspective to determine whether this was simply a legitimate act of war or a war crime. On the one hand, Chris Hani was a leader of a movement openly engaged in an armed struggle against the apartheid regime and, on the other, it was common knowledge that the armed struggle had been suspended in favor of a negotiated settlement of the conflict.

The most troubling case, however, is that of the St. James Church massacre in which 11 people were killed and 58 wounded. In this case the Committee granted amnesty to three PAC members, Gcinikhaya Makoma, Bassie Mzukisi Mkhumbuzi and Tobela Mlambisi, who were responsible for the attack. According to their testimony, the applicants were acting on the orders of APLA, the military wing of the PAC, when they threw a hand grenade into St. James Church and fired indiscriminately at the churchgoers inside. Notwithstanding the objections of some of the victims' relatives, the Committee found that the attack was not disproportionate to the PAC's political objectives. According to APLA's submission, they saw "every white South African as a pillar of apartheid protecting white South Africa from the Black danger," and believed that the government was engaged "in the process of arming the entire White South African Society. This militarisation, therefore, of necessity made every white citizen a member of the security establishment." ${ }^{33}$

This case does not appear to merit the respect of the international community. As non-combatants, the churchgoers in this case clearly fall within the category of protected persons recognized by international humanitarian law. While there may certainly have been extenuating circumstances in this case that mitigate the assailants' blameworthiness, it is doubtful whether the result is sufficient to absolve the assailants of their accountability under international law.

As these contrasting decisions demonstrate, it is possible for a state to make good faith efforts to deal with the crimes of the past in a manner that generally meets the expectations of the international community. However, even in such cases, political considerations may still produce unacceptable results in some individual cases. As a result, the international community will need to examine

Truth and Reconciliation Commission, Amnesty Committee AC/99/0172 (S. Afr.), available in Decisions (visited February 23, 2000) <http://www.truth.org.za/ >.

53 "Application In Terms Of Section 18 Of The Promotion Of National Unity And Reconciliation Act, No. 34 Of 1995", Gcinikhaya Makoma et al. Applicants, Truth and Reconciliation Commission, Amnesty Committee AC/98/0018 (S. Afr.), available in Decisions (visited February 23, 2000) <http://www.truth.org.za/>. 
each case individually to determine whether an international crimes has occurred and whether universal jurisdiction should be exercised to bring those responsible to justice.

\section{Conclusion}

Legal developments and state practice over the past fifty years have resulted in the evolution of principles of accountability reflecting the expectations of the international community and the requirements of international law. As a result, states are no longer unfettered in their decisions about how to deal with the gross violations of the past. Not only must states investigate these abuses, they must also undertake reforms and adopt measures to prevent their repetition and provide redress to the victims. In addition they must also prosecute those responsible for serious abuses if this is the most effective method to deter similar abuses in the future. Moreover, where these abuses amount to international crimes, they are now subject to universal jurisdiction, which requires that states either prosecute or extradite the suspected perpetrators.

To the extent that amnesty laws are adopted to deal with the crimes of the past, states can no longer expect unqualified deference on the part of the international community towards their domestic efforts. In particular, the international community will not respect a self-amnesty or blanket amnesty, or any other measure with the same effect. Instead, states wishing to adopt amnesty laws need to do so on an individualized and conditional basis. In this regard, international law does not yet offer explicit guidance as to the criteria to be used. However, as the South African precedent demonstrates, guidance can readily be found in state practice applying the political offence exception to extradition. Insofar as state practice now includes restrictions on the application of the political offence exception, states must be sure to incorporate these into their amnesty criteria. This may be done by adopting specific criteria that exclude crimes against humanity and war crimes from the ambit of the political offence exception, or by adopting a general requirement of proportionality, as done in the case of South Africa.

In the end, whether the international community will respect the amnesties a state has granted in dealing with serious human rights abuses of the past will depend on how carefully the selection criteria were defined and applied. Furthermore, as demonstrated by the adoption of the Rome Statute, it is the international community alone that will decide whether or not to respect a state's domestic efforts at accountability. 